\title{
Porozumienie o wolnym handlu między Unią Europejską i Koreą Południową - perspektywy dla polskich eksporterów
}

\section{Free Trade Agreement between the European Union and South Korea. Perspectives for Polish exporters}

\begin{abstract}
The aim of the article is to analyse the main effects of trade liberalisation in the framework of the Free Trade Agreement between the European Union and South Korea (FTA) and to identify prospects for Polish exporters. The following hypothesis has been adapted: the FTA creates a significant impulse for the intensification of bilateral trade but there are still barriers to trade development. Generally, chances arising from the agreement are used more effectively by the European than by individual member states, including Poland. The study is based on data analysis, reports and studies conducted by various research centres. The results of the study support the hypothesis. A systematic increase in the volume of trade in goods has been observed since FTA came into force. In the case of Poland, there is still a negative balance of trade in goods. It results from various factors (internal and external), including the existence of regulatory and administrative barriers as well as market-related obstacles to entering the South Korean market.
\end{abstract}

Keywords: free trade agreement, foreign trade, export, European Union, Poland, South Korea Słowa kluczowe: umowa o wolnym handlu, handel zagraniczny, eksport, Unia Europejska, Polska, Korea Południowa

\section{Wstęp}

W warunkach globalizacji, wzrostu oraz intensyfikacji powiązań i współzależności między gospodarkami i ich podmiotami w różnych sferach (zwłaszcza gospodarczej) uczestnicy światowego handlu poszukują sposobów wzmacniania konkurencyjności na poziomie międzynarodowym, wśród których istotną rolę odgrywa polityka handlowa. Celami sformułowanej w 2006 r. przez Unię Europejską strategii „Global Europe. Competing 
in the World" są redukcja celnych i pozacelnych barier w handlu UE z jej partnerami oraz liberalizacja dostępu do rynków dla europejskich podmiotów. Istotne znaczenie dla ich realizacji mają porozumienia o wolnym handlu (FTA - free trade agreement) nowej generacji ${ }^{1}$. Jako główne ekonomiczne kryteria wyboru partnerów, z którymi można podjąć negocjacje, należy wymienić: ich duży potencjał rynkowy, znaczne korzyści ze zniesienia taryfowych i pozataryfowych barier w ramach porozumienia o wolnym handlu oraz podjęte przez potencjalnego partnera negocjacje z konkurentami UE. Od lat sześćdziesiątych XX w. rządy Korei Południowej wspierały rozwój przemysłowy nastawiony na zwiększenie eksportu i zmniejszenie importu towarów konsumpcyjnych ${ }^{2}$. Jednocześnie promowano działania związane z rozwojem nowych technologii i podnoszeniem innowacyjności gospodarki. Początek XXI w. to zmiana w polityce handlowej polegająca na wdrażaniu strategii większej integracji z gospodarką światową poprzez negocjowanie porozumień handlowych o charakterze preferencyjnym. Władze Korei oceniały geoekonomiczne położenie kraju jako trudne. W bliskim sąsiedztwie tego liczącego ok. 51 mln mieszkańców państwa znajduje się z jednej strony Japonia, specjalizująca się w produkcji i eksporcie dóbr wysokich technologii, z drugiej zaś Chiny, oferujące coraz bardziej konkurencyjne towary ${ }^{3}$. Południowa część Półwyspu Koreańskiego jest uboga w surowce naturalne, dlatego też w proeksportowo nastawionej gospodarce konieczny jest ich import. Powoduje to, że rozwój Korei Południowej w dużej mierze determinowany jest przez możliwości eksportowe i importowe, a więc przez jak najbardziej liberalne stosunki z głównymi partnerami handlowymi. Rząd południowokoreański przyjął strategię Global Korea, mającą na celu wzmacnianie konkurencyjności gospodarki poprzez zwiększenie zaangażowania i obecność kraju w gospodarce światowej w wyniku zawierania porozumień o wolnym handlu4 ${ }^{4}$ Zbieżność wizji polityki handlowej Unii Europejskiej i Korei Południowej jest czynnikiem sprzyjającym partnerstwu

1 Global Europe. Competing in the World. A contribution to the EU's growth and job strategy, Brussels 2006, s. 10.

2 Korea as a knowledge economy. Evolutionary process and lessons learned, ed. J. Suh, D.H.C. Chen, The World Bank, Washington DC 2007, s. 20.

3 Trade boosts, Country Monitor, The Economist Intelligence Unit, 4.07.2011, s. 4.

4 W.H. Cooper, R. Jurenas, M.D. Platzer, M.E. Manyin, The EU-South Korea free trade agreement and its implications for the United States, „Congressional Research Service" [online], 1.12.2011 [dostęp: 25.10.2018], s. 6, dostępny w internecie: <http://digitalcommons.ilr.cornell.edu/key_workplace/795>; D.K. Das, The EU-Korea free trade agreement. Making of a “deep” free trade agreement, „Global Economy Journal” 2012, vol. 12, issue 1, s. 5 . 
ekonomicznemu i można go uznać za główną przyczynę podpisania porozumienia o wolnym handlu między oboma podmiotami. Nie bez znaczenia są także położenie geograficzne Korei w regionie Azji Wschodniej, którego pozycja w gospodarce światowej i międzynarodowym podziale pracy rośnie, oraz zwiększająca się aktywność inwestycyjna południowokoreańskich podmiotów na rynku unijnym. Dla Korei istotnym czynnikiem atrakcyjności UE jako rynku zbytu jest jego duży rozmiar, pozwalający na osiąganie korzyści skali, czemu dodatkowo sprzyja brak barier wynikający ze swobodnego przepływu towarów między krajami wspólnoty.

W niniejszym artykule przyjęto następującą hipotezę badawczą: Porozumienie o wolnym handlu między Unią Europejską a Koreą Południową stało się istotnym impulsem intensyfikacji dwustronnej wymiany handlowej, ale wciąż istnieją bariery dla jej rozwoju. Unia jako całość lepiej wykorzystuje szanse wynikające z umowy niż poszczególne kraje UE, w tym Polska.

Autorka stara się odpowiedzieć na następujące pytania: 1. Jak kształtowała się wymiana handlowa między Unią Europejską (w tym Polską) a Koreą Południową przed podpisaniem porozumienia o wolnym handlu i po jego zawarciu? 2. Jakie są główne efekty liberalizacji handlu między UE i Koreą Południową? 3. Jakie istnieją bariery $\mathrm{w}$ dwustronnej wymianie handlowej? 4. Jakie są perspektywiczne obszary rozwoju współpracy handlowej dla polskich eksporterów? 5. Jakie działania z zakresu dyplomacji gospodarczej podejmowane są, aby wspierać polskie przedsiębiorstwa w eksporcie towarów na rynek południowokoreański?

W artykule skoncentrowano się na analizie handlu towarami mającymi istotne znaczenie w strukturze dwustronnej wymiany handlowej. Pierwsza część tekstu dotyczy działań podejmowanych przez WE/UE w obszarze rozwoju stosunków handlowych z Koreą Południową wraz z opisem głównych założeń porozumienia o wolnym handlu z $2011 \mathrm{r}$. W drugiej przedstawiono kształtowanie się wielkości i struktury wymiany towarowej Unii Europejskiej z Koreą Południową w latach 2010-2016 (przed wejściem w życie umowy o wolnym handlu i po jej zawarciu), a w trzeciej - wymiany towarowej Polski z Koreą Południową w badanym okresie. Część czwarta zawiera prezentację głównych rezultatów porozumienia o wolnym handlu między UE i Koreą Południową oraz najważniejszych barier dla rozwoju dwustronnej wymiany towarowej. W piątej wskazano zaś perspektywy dla polskich eksporterów, z uwzględnieniem możliwości i uwarunkowań zwiększenia aktywności eksportowej na rynku południowokoreańskim. Problematyka poruszana w artykule jest punktem wyjścia do dalszych badań. 


\section{W kierunku porozumienia o wolnym handlu UE-Korea Południowa. Główne założenia}

Jednym z pierwszych działań mających na celu rozwój dwustronnych stosunków handlowych między Wspólnotą Europejską a Koreą Południową było podpisanie w 1997 r. umowy o współpracy i wzajemnej pomocy administracyjnej w sprawach celnych. Jej głównym założeniem było rozwijanie kontaktów handlowych i zapewnienie przy tym właściwego ustalania należności celnych i innych opłat ${ }^{5}$. Zgodnie $\mathrm{z}$ art. 15 umowy ustanowiono Wspólny Komitet Współpracy Celnej, którego zadaniem było m.in. przygotowanie przeglądu współpracy celnej oraz wskazanie nowych dziedzin i perspektywicznych sektorów kooperacji. Następnym ważnym porozumieniem była umowa między Wspólnotą Europejską a rządem Korei Południowej dotycząca współpracy w sprawie działań antykonkurencyjnych. Zawarto ją w następstwie przyjęcia w 2004 r. protokołu ustaleń między Dyrekcją Generalną ds. Konkurencji Komisji Europejskiej a Komisją ds. Uczciwej Konkurencji Korei Południowej. Umowa zaczęła obowiązywać 1 lipca 2009 r., a jej głównym celem było skuteczne egzekwowanie praw konkurencji, co miało się przyczynić do bardziej efektywnego funkcjonowania rynków i wymiany handlowej ${ }^{6}$. Negocjowanie porozumienia o wolnym handlu między Unią Europejską a Koreą Południową rozpoczęto w maju 2007 r. w Seulu. Po ośmiu rundach formalnych rozmów 15 października 2009 r. parafowana została pierwsza umowa handlowa pomiędzy Unią Europejską a państwem azjatyckim. Strony oczekiwały, że wdrożenie jej zapisów przyczyni się do pobudzenia dwustronnej wymiany handlowej i wzrostu gospodarczego w UE i Korei Południowej, ale również odbije się głośnym echem w Azji i innych regionach świata, sygnalizując otwartość UE na relacje biznesowe z państwami trzecimi oraz jej zaangażowanie w negocjowanie kolejnych porozumień o wolnym handlu, np. z Chinami. 16 września 2010 r. umowa została zatwierdzona przez Radę UE, a do jej oficjalnego podpisania doszło 6 października, podczas unijno-koreańskiego szczytu w Brukseli. Parlament Europejski zgodę na zawarcie umowy wyraził 17 lutego 2011 r. Tymczasowo stosowano ją od 1 lipca 2011 r., a po ratyfikacji przez wszystkie

5 Umowa między Wspólnotą Europejska a Republika Korei o wspótpracy $i$ wzajemnej pomocy administracyjnej w sprawach celnych, Dz.U. UE, 1997, L 121/14.

6 Umowa między Wspólnota Europejską a rządem Republiki Korei dotyczaca wspótpracy w sprawie działań antykonkurencyjnych, Dz.U. UE, 2009, L 202/36, art. 1. 
kraje członkowskie UE weszła w życie 13 grudnia 2015 r. Dokument zawiera 15 rozdziałów, kilkanaście załączników, 3 protokoły oraz 4 uzgodnienia. Wzajemna liberalizacja potraktowana została szeroko. Oprócz wymiany towarowej objęła ułatwienia w handlu usługami (m.in. w zakresie ochrony środowiska, telekomunikacji, żeglugi, finansów i prawa), a także postanowienia dotyczące przepływu kapitału w formie inwestycji - zarówno w sektorze usługowym, jak i przemysłowym. W umowie znalazły się też zapisy dotyczące promowania konkurencji, wzajemnej liberalizacji rynku zamówień publicznych i ochrony praw własności intelektualnej (w tym oznaczeń geograficznych). Włączono do niej również protokół w sprawie współpracy kulturalnej, który zawiera zobowiązanie obu stron do promowania różnorodności kulturowej zgodnie z konwencją UNESCO ${ }^{7}$. Zapisy dotyczące eliminacji ograniczeń taryfowych i pozataryfowych w handlu towarami, a także postanowienia odnoszące się do stosowania narzędzi polityki handlowej, barier technicznych w handlu, kwestii sanitarnych i fitosanitarnych, ułatwień celnych oraz handlu usługami potraktowane zostały dość szczegółowo. W wielu miejscach strony odwołują się do porozumień podpisanych $\mathrm{w}$ ramach WTO (Korea Południowa jest jej członkiem od 1 stycznia 1995 r.), jednak zawarte $\mathrm{w}$ nich postanowienia zostały nie tylko poszerzone, ale i pogłębione. W 2009 r. stawki celne związane z wejściem na rynek południowokoreański wynosiły średnio 35\%. Uzgodniono, że od 1 lipca 2011 do 1 lipca 2016 r. obie strony będą stopniowo znosić cła na dobra przemysłowe. Liberalizacja dotyczyła 98\% towarów, za wyjątkiem części artykułów rolno-spożywczych i produktów rybołówstwa objętych dłuższymi okresami przejściowymi (7 lat i więcej) ${ }^{8}$. Szczegółowy opis procesu znoszenia ceł zamieszczono w załączniku 2-A: Zniesienie należności celnych do umowy o wolnym handlu między Unią Europejską a Koreą Południową . Uzgodniono też szczególne zobowiązania dotyczące likwidacji pozataryfowych barier w handlu i przeciwdziałania ich powstawaniu, zwłaszcza w takich sektorach, jak motoryzacja, produkty farmaceutyczne i elektronika użytkowa.

7 Umowa o wolnym handlu między Unia Europejska i jej państwami członkowskimi z jednej strony a Republika Korei z drugiej strony, Dz.U. UE, 2011, L 127/6, art. 1.1.

8 Umowa o wolnym handlu między UE a Republika Korei, EUR-Lex [online], 14.06.2017 [dostęp: 26.10.2018], dostępny w internecie: <https://eur-lex.europa.eu/legal-content/ PL/TXT/HTML/?uri=LEGISSUM:rx0032\&from=PL $>$.

9 Dz.U. UE, 2011, L127/81, t. 54, dostępny w internecie [dostęp: 26.10.2018]: <https:// eur-lex.europa.eu/legal-content/PL/TXT/?uri=OJ\%3AL\%3A2011\%3A127\%3ATOC>. 


\section{Wielkość i struktura wymiany towarowej Unii Europejskiej z Koreą Południową}

Badanie dotyczy kształtowania się wymiany towarowej Unii Europejskiej z Koreą Południową w latach 2010-2016, czyli przed zawarciem umowy o wolnym handlu i po jej wejściu w życie.

Analiza wielkości wymiany towarowej między UE a Koreą Południową zgodnie z Międzynarodową Standardową Klasyfikacją Handlu (SITC) ${ }^{10}$ wskazuje na zwiększanie się wartości eksportu i importu w badanym okresie, zwłaszcza w odniesieniu do krajów strefy euro. Od 2011 r. deficyt w bilansie handlowym wspólnoty z tym krajem zmniejsza się. W 2013 r. Unia Europejska odnotowała dodatnie saldo (4,073 mld euro), a w 2016 wyniosło ono 2,467 mld euro. Strefa euro nadwyżkę w bilansie handlowym miała już w 2011 r., a w 2016 osiągnęła ona wartość 6,963 mld euro (tabela 1).

\section{Tabela 1. Eksport, import i bilans handlowy UE oraz strefy euro w wymianie towarowej z Koreą Południową \\ w latach 2010-2016 (w mld euro)}

\begin{tabular}{|c|c|c|c|c|c|c|c|c|}
\hline & & 2010 & 2011 & 2012 & 2013 & 2014 & 2015 & 2016 \\
\hline \multirow{3}{*}{ UE } & eksport & 27,961 & 32,514 & 37,815 & 39,911 & 43,192 & 47,794 & 44,111 \\
\hline & import & 39,534 & 36,312 & 38,014 & 35,837 & 38,771 & 42,365 & 41,643 \\
\hline & $\begin{array}{l}\text { bilans } \\
\text { handlowy }\end{array}$ & $\begin{array}{c}\text { deficyt } \\
(-11,573)\end{array}$ & $\begin{array}{c}\text { deficyt } \\
(-3,797)\end{array}$ & $\begin{array}{c}\text { deficyt } \\
(-0,199)\end{array}$ & $\begin{array}{c}\text { nadwyżka } \\
(+4,073)\end{array}$ & $\begin{array}{c}\text { nadwyżka } \\
(+4,421)\end{array}$ & $\begin{array}{c}\text { nadwyżka } \\
(+5,428)\end{array}$ & $\begin{array}{c}\text { nadwyżka } \\
(+2,467)\end{array}$ \\
\hline \multirow{3}{*}{$\begin{array}{l}\text { Strefa } \\
\text { euro }\end{array}$} & eksport & 23,112 & 26,934 & 29,200 & 31,066 & 35,004 & 37,814 & 35,254 \\
\hline & import & 28,572 & 26,657 & 27,351 & 25,795 & 26,318 & 27,782 & 28,290 \\
\hline & $\begin{array}{l}\text { bilans } \\
\text { handlowy }\end{array}$ & $\begin{array}{c}\text { deficyt } \\
(-5,460)\end{array}$ & $\begin{array}{c}\text { nadwyżka } \\
(+0,277)\end{array}$ & $\begin{array}{c}\text { nadwyżka } \\
(+1,849)\end{array}$ & $\begin{array}{c}\text { nadwyżka } \\
(+5,270)\end{array}$ & $\begin{array}{c}\text { nadwyżka } \\
(+8,685)\end{array}$ & $\begin{array}{l}\text { nadwyżka } \\
(+10,032)\end{array}$ & $\begin{array}{c}\text { nadwyżka } \\
(+6,963)\end{array}$ \\
\hline
\end{tabular}

Źródło: oprac. własne na podstawie: Trade. Market Access Database [2017], „European Commission" [online, dostęp: 9.09.2017], dostępny w internecie: <http://madb.europa.eu/ madb/statistical_form.htm>.

Kraje strefy euro: Niemcy, Włochy, Francja, Holandia, Hiszpania oraz Belgia wraz z Luksemburgiem należą do największych unijnych eksporterów na rynek południowokoreański (tabela 2).

10 Sekcja 0: „Żywność i zwierzęta żywe”; sekcja 1: „Napoje i tytoń”; sekcja 2: „Surowce niejadalne z wyjątkiem paliw”; sekcja 3: „Paliwa mineralne, smary i materiały pochodne”; sekcja 4: „Oleje, thuszcze i woski zwierzęce i roślinne”; sekcja 5: „Chemikalia i produkty pokrewne”; sekcja 6: „Towary przemysłowe sklasyfikowane głównie według surowca”; sekcja 7: „Maszyny, urządzenia i sprzęt transportowy”; sekcja 8: „Różne wyroby przemysłowe”; sekcja 9: „Towary i transakcje niesklasyfikowane w SITC”. 
Tabela 2. Najwięksi unijni partnerzy handlowi Korei Południowej w 2016 r.

\begin{tabular}{|l|c|c|l|c|c|}
\hline \multicolumn{2}{|c|}{ Eksporterzy } & \multicolumn{3}{c|}{ Importerzy } \\
\hline kraj & $\begin{array}{c}\text { wartość } \\
\text { eksportu } \\
\text { (mld euro) }\end{array}$ & $\begin{array}{c}\text { udzial } \\
\text { w unijnym } \\
\text { eksporcie } \\
\text { do Korei Pld. } \\
\text { (\%) }\end{array}$ & kraj & $\begin{array}{c}\text { wartość } \\
\text { importu } \\
\text { (mld euro) }\end{array}$ & $\begin{array}{c}\text { udzial } \\
\text { w unijnym } \\
\text { imporcie } \\
\text { z Korei Pld. } \\
\text { (\%) }\end{array}$ \\
\hline Niemcy & 17,356 & 39,0 & Niemcy & 6,402 & 15,4 \\
\hline Wielka Brytania & 5,307 & 12,0 & Wielka Brytania & 5,469 & 13,1 \\
\hline Wlochy & 3,988 & 9,0 & Holandia & 4,025 & 9,7 \\
\hline Francja & 3,895 & 9,8 & Slowacja & 3,222 & 7,7 \\
\hline Holandia & 3,839 & 8,7 & Wlochy & 2,966 & 7,1 \\
\hline Hiszpania & 1,639 & 3,7 & Francja & 2,464 & 5,9 \\
\hline $\begin{array}{l}\text { Belgia wraz } \\
\text { z Luksemburgiem }\end{array}$ & 1,440 & 3,3 & Czechy & 2,412 & 5,8 \\
\hline Szwecja & 1,268 & 2,9 & Polska & 2,405 & 5,8 \\
\hline
\end{tabular}

Źródło: oprac. własne na podstawie: Trade. Market Access Database [2017], „European Commission" [online, dostęp: 16.10.2018], dostępny w internecie: $<$ http://madb.europa.eu/ madb/statistical_form.htm>

Najwięksi unijni eksporterzy na rynek południowokoreański to kraje wysoko rozwinięte, korzystające w handlu zagranicznym z możliwości, jakie oferuje Jednolity Rynek Europejski, ale też od wielu lat obecne na rynkach pozaunijnych. Dysponują one konkurencyjną ofertą, sprzedając głównie produkty wysoko przetworzone z dużą wartością dodaną. Przykładem są Niemcy, będące liderem w wymianie handlowej z Koreą Południową z 39\% udziałem w całkowitym unijnym eksporcie do tego kraju. Zajmują one również pierwsze miejsce wśród największych importerów, z 15,4\% udziału w całkowitym unijnym imporcie z Korei. W badanym okresie wartość nadwyżki w bilansie handlowym Niemiec z tym krajem zwiększyła się prawie 39 razy: w $2010 \mathrm{r}$. wynosiła 283 mln euro, a w 2016 - 10,9 mld euro.

W 2016 r. zgodnie z SITC w obrotach handlowych UE z Koreą Południową największy udział miały „Maszyny, urządzenia i sprzęt transportowy” (w eksporcie $50,3 \%$, w imporcie $60,0 \%$ ). Istotnymi sekcjami unijnego eksportu były także „Chemikalia i produkty pokrewne” $(15,8 \%)$ oraz „Różne wyroby przemysłowe” (12,5\%). W stosunku do 2015 r. wzrósł eksport w sekcjach: „Napoje i tytoń” oraz „Żywność i zwierzęta żywe”, a spadł w pozostałych, szczególnie w sekcji „Paliwa mineralne, smary i materiały pochodne”. W unijnym imporcie z Korei Południowej oprócz sekcji „Maszyny, urządzenia i sprzęt transportowy” istotne są: ,Towary przemysłowe sklasyfikowane głównie według surowca”, „Chemikalia i produkty pokrewne” oraz „Różne wyroby przemysłowe”. 


\section{Wielkość i struktura wymiany towarowej Polski z Koreą Południową}

W latach 2010-2016 wymiana towarowa Polski z Koreą Południową charakteryzowała się wzrostem wartości zarówno eksportu, jak i importu. W $2016 \mathrm{r}$. Polska wyeksportowała towary o łącznej wartości ponad $456 \mathrm{mln}$ euro, importując w tym czasie produkty za 2,4 mld euro. Choć Korea Południowa jest krajem, z którym Polska ma deficyt w wymianie towarowej, to w ostatnich latach ujemne saldo zmniejsza się (z ok. $-2,2$ mld euro w 2014 r. do ok. $-1,9$ mld euro w 2016).

Tabela 3. Wymiana towarowa Polski z Koreą Południową w latach 2010-2016 (w mld euro)

\begin{tabular}{|c|c|c|c|}
\hline Rok & Eksport & Import & Saldo \\
\hline 2010 & 0,210 & 2,711 & $-2,502$ \\
\hline 2011 & 0,298 & 2,364 & $-2,066$ \\
\hline 2012 & 0,415 & 2,581 & $-2,166$ \\
\hline 2013 & 0,543 & 2,258 & $-1,715$ \\
\hline 2014 & 0,379 & 2,553 & $-2,174$ \\
\hline 2015 & 0,382 & 2,364 & $-1,982$ \\
\hline 2016 & 0,457 & 2,406 & $-1,949$ \\
\hline
\end{tabular}

Źródło: Trade. Market Access Database [2017], „European Commission” [online, dostęp: 9.09.2017], dostępny w internecie: $<$ http://madb.europa.eu/madb/statistical_form.htm $>$

$\mathrm{Z}$ analizy struktury wymiany towarowej między Polską a Koreą Południową zgodnie z SITC wynika, że w 2016 r. w polskim eksporcie do tego kraju największy udział miały: „Towary przemysłowe sklasyfikowane głównie według surowca” (36,2\%), „Maszyny, urządzenia i sprzęt transportowy” (ok. 34,9\%), „Chemikalia i produkty pokrewne” (ok. 12,1\%) oraz „Różne wyroby przemysłowe” (9,0\%). W imporcie z Korei Południowej największy udział miały: „Maszyny, urządzenia i sprzęt transportowy” $(61,1 \%)$, „Towary przemysłowe sklasyfikowane głównie według surowca” (13,9\%), „Różne wyroby przemysłowe” (11,9\%) oraz „Chemikalia i produkty pokrewne" (10,9\%). Uwzględniając SITC, Polska odnotowała w badanym okresie wzrost wartości eksportu w każdej sekcji oprócz „Surowce niejadalne z wyjątkiem paliw", w której obserwuje się spadek. Dodatnie saldo bilansu handlowego w wymianie towarowej z Koreą Południową za rok 2016 odnotowano jedynie w dwóch sekcjach: „Żywność i zwierzęta żywe” oraz „Paliwa mineralne, smary i materiały pochodne". W pozostałych import dominuje nad eksportem. 


\section{Efekty porozumienia o wolnym handlu między UE i Koreą Południową}

Według danych Międzynarodowego Funduszu Walutowego w 2016 r. Unia Europejska zajmowała 3. pozycję wśród najważniejszych partnerów handlowych Korei Południowej (2. w imporcie i 3. w eksporcie) z 10\% udziału w całości wymiany handlowej tego państwa $\mathrm{z}$ resztą świata, plasując się za Chinami (1. pozycja; 23,4\%) i Stanami Zjednoczonymi (2. pozycja; $12,5 \%$ ), a przed Japonią (4. pozycja; 8\%), Wietnamem (5. pozycja; 5\%), Hongkongiem (6. pozycja; 3,8\%), Tajwanem (7. pozycja; 3,2\%), Australią (8. pozycja; 2,5\%), Arabią Saudyjską (9. pozycja; 2,4\%). Korea Południowa zajmowała z kolei 8. pozycję wśród najważniejszych partnerów handlowych Unii Europejskiej (8. pozycja w imporcie i eksporcie) z 2,5\% udziału w całości wymiany handlowej UE z resztą świata, lokując się za Stanami Zjednoczonymi (1. pozycja; 17,7\%), Chinami (2. pozycja; 14,9\%), Szwajcarią (3. pozycja; 7,6\%), Federacją Rosyjską (4. pozycja; 5,5\%), Turcją (5. pozycja; 4,2\%), Japonią (6. pozycja; 3,6\%), Norwegią (7. pozycja; 3,2\%), a przed Indiami (9. pozycja; 2,2\% ${ }^{11}$. Zarówno dla UE, jak i Korei Południowej głównymi partnerami w handlu są Stany Zjednoczone oraz Chiny. Ponadto należy odnotować, że dla Korei rynek unijny jest ważniejszy niż południowokoreański dla Unii Europejskiej. W przypadku Polski jest podobnie: według danych GUS w 2016 r. Korea zajmowała 44. pozycję wśród 236 krajów importujących towary z Polski ( $0,25 \%$ udziału w całkowitym polskim eksporcie) i 15 . wśród eksporterów nad Wisłę (1,7\% udziału w całkowitym imporcie Polski) ${ }^{12}$.

Porozumienie o wolnym handlu między UE i Koreą Południową miało istotne znaczenie dla rozwoju dwustronnej wymiany towarowej. Przedsiębiorstwa z UE, w tym z Polski, uzyskały łatwiejszy dostęp do rynku południowokoreańskiego, podobnie jak przedsiębiorstwa z Korei do rynku Wspólnoty. Unia Europejska (zwłaszcza strefa euro) lepiej wykorzystuje szanse wynikające z liberalizacji obrotów handlowych z Koreą Południową niż Polska. Zwiększając głównie eksport,

11 European Commission, Directorate-General for Trade, European Union, Trade in goods with South Korea, 3.05.2017, s. 8-9.

12 Główni partnerzy Polski w eksporcie towarów: Niemcy $(27,38 \%$ udziału w całkowitym eksporcie), Wielka Brytania (6,65\%), Czechy (6,57\%), Francja (5,50\%), Włochy (4,77\%), Holandia (4,48\%), Szwecja (2,90\%), Rosja (2,82\%), Hiszpania (2,72\%), Węgry $(2,65 \%)$. Główni partnerzy Polski w imporcie towarów: Niemcy $(23,29 \%$ udziału w całkowitym imporcie), Chiny (11,98\%), Rosja (5,76\%), Włochy $(5,56 \%)$, Francja (3,98\%), Holandia (3,84\%), Czechy (3,62\%), Stany Zjednoczone (2,81\%), Belgia (2,65\%), Wielka Brytania (2,58\%). Obroty handlu zagranicznego wedtug krajów, GUS, 2016, dostępny w internecie [dostęp: 16.10.2018] <www.swaid.stat.gov.pl>. 
istotnie ograniczyła dotychczasowy deficyt handlowy. W 2010 r., przed wejściem w życie tymczasowej umowy o wolnym handlu UE z Koreą Południową, dodatnie saldo bilansu handlowego z tym krajem miało 8 członków UE: Bułgaria, Dania, Estonia, Finlandia, Francja, Holandia, Irlandia i Niemcy, a w 2016, czyli rok po wejściu w życie pełnej umowy - 10 krajów: Austria, Dania, Estonia, Finlandia, Francja, Irlandia, Łotwa, Niemcy, Szwecja i Włochy. Z problemem ujemnego bilansu handlowego z Koreą Południową mierzy się większość, bo 16 państw członkowskich UE (tabela 4).

Tabela 4. Bilans handlowy państw czlonkowskich UE w wymianie towarowej z Koreą Południową w latach 2010-2016 (w mld euro)

\begin{tabular}{|c|c|c|c|c|c|c|c|}
\hline Państwo & 2010 & 2011 & 2012 & 2013 & 2014 & 2015 & 2016 \\
\hline Austria & $\begin{array}{c}\text { deficyt } \\
(-0,136)\end{array}$ & $\begin{array}{c}\text { nadwyżka } \\
(+0,328)\end{array}$ & $\begin{array}{c}\text { nadwyżka } \\
(+0,329)\end{array}$ & $\begin{array}{c}\text { nadwyżka } \\
(+0,216)\end{array}$ & $\begin{array}{c}\text { nadwyżka } \\
(+0,251)\end{array}$ & $\begin{array}{c}\text { nadwyżka } \\
(+0,230)\end{array}$ & $\begin{array}{c}\text { nadwyżka } \\
(+0,250)\end{array}$ \\
\hline $\begin{array}{l}\text { Belgia wraz } \\
\text { z Luksem- } \\
\text { burgiem }\end{array}$ & $\begin{array}{c}\text { deficyt } \\
(-0,501)\end{array}$ & $\begin{array}{c}\text { deficyt } \\
(-0,137)\end{array}$ & $\begin{array}{c}\text { nadwyżka } \\
(+0,174)\end{array}$ & $\begin{array}{c}\text { deficyt } \\
(-0,703)\end{array}$ & $\begin{array}{c}\text { deficyt } \\
(-0,555)\end{array}$ & $\begin{array}{c}\text { deficyt } \\
(-0,494)\end{array}$ & $\begin{array}{c}\text { deficyt } \\
(-0,594)\end{array}$ \\
\hline Bulgaria & $\begin{array}{c}\text { nadwyżka } \\
(+0,019)\end{array}$ & $\begin{array}{c}\text { deficyt } \\
(-0,023)\end{array}$ & $\begin{array}{c}\text { nadwyżka } \\
(+0,023)\end{array}$ & $\begin{array}{c}\text { nadwyżka } \\
(+0,033)\end{array}$ & $\begin{array}{c}\text { deficyt } \\
(-0,010)\end{array}$ & $\begin{array}{c}\text { deficyt } \\
(-0,031)\end{array}$ & $\begin{array}{c}\text { deficyt } \\
(-0,029)\end{array}$ \\
\hline Chorwacja* & $\begin{array}{c}\text { deficyt } \\
(-0,124)\end{array}$ & $\begin{array}{c}\text { deficyt } \\
(-0,117)\end{array}$ & $\begin{array}{c}\text { deficyt } \\
(-0,101)\end{array}$ & $\begin{array}{c}\text { deficyt } \\
(-0,065)\end{array}$ & $\begin{array}{c}\text { deficyt } \\
(-0,072)\end{array}$ & $\begin{array}{c}\text { deficyt } \\
(-0,117)\end{array}$ & $\begin{array}{c}\text { deficyt } \\
(-0,401)\end{array}$ \\
\hline Cypr & $\begin{array}{c}\text { deficyt } \\
(-0,038) \\
\end{array}$ & $\begin{array}{c}\text { deficyt } \\
(-0,020)\end{array}$ & $\begin{array}{c}\text { deficyt } \\
(-0,015) \\
\end{array}$ & $\begin{array}{c}\text { deficyt } \\
(-0,013) \\
\end{array}$ & $\begin{array}{c}\text { deficyt } \\
(-0,011) \\
\end{array}$ & $\begin{array}{c}\text { deficyt } \\
(-0,009)\end{array}$ & $\begin{array}{c}\text { deficyt } \\
(-0,309) \\
\end{array}$ \\
\hline Czechy & $\begin{array}{c}\text { deficyt } \\
(-0,776)\end{array}$ & $\begin{array}{c}\text { deficyt } \\
(-1,125)\end{array}$ & $\begin{array}{c}\text { deficyt } \\
(-1,442)\end{array}$ & $\begin{array}{c}\text { deficyt } \\
(-1,094)\end{array}$ & $\begin{array}{c}\text { deficyt } \\
(-1,141)\end{array}$ & $\begin{array}{c}\text { deficyt } \\
(-1,868)\end{array}$ & $\begin{array}{c}\text { deficyt } \\
(-2,013)\end{array}$ \\
\hline Dania & $\begin{array}{c}\text { nadwyżka } \\
(+0,167)\end{array}$ & $\begin{array}{c}\text { nadwyżka } \\
(+0,239)\end{array}$ & $\begin{array}{c}\text { nadwyżka } \\
(+0,285)\end{array}$ & $\begin{array}{c}\text { deficyt } \\
(-0,235)\end{array}$ & $\begin{array}{c}\text { deficyt } \\
(-0,870)\end{array}$ & $\begin{array}{c}\text { deficyt } \\
(-0,727)\end{array}$ & $\begin{array}{c}\text { nadwyżka } \\
(+0,340)\end{array}$ \\
\hline Estonia & $\begin{array}{c}\text { nadwyżka } \\
(+0,005)\end{array}$ & $\begin{array}{c}\text { deficyt } \\
(-0,007)\end{array}$ & $\begin{array}{c}\text { nadwyżka } \\
(+0,016)\end{array}$ & $\begin{array}{c}\text { nadwyżka } \\
(+0,028)\end{array}$ & $\begin{array}{c}\text { nadwyżka } \\
(+0,019)\end{array}$ & $\begin{array}{c}\text { nadwyżka } \\
(+0,010)\end{array}$ & $\begin{array}{c}\text { nadwyżka } \\
(+0,001)\end{array}$ \\
\hline Finlandia & $\begin{array}{c}\text { nadwyżka } \\
(+0,350)\end{array}$ & $\begin{array}{c}\text { nadwyżka } \\
(+0,129)\end{array}$ & $\begin{array}{c}\text { nadwyżka } \\
(+0,134) \\
\end{array}$ & \begin{tabular}{|c|} 
nadwyżka \\
$(+0,671)$
\end{tabular} & $\begin{array}{c}\begin{array}{c}\text { nadwyżka } \\
(+0,688)\end{array} \\
\end{array}$ & $\begin{array}{c}\text { nadwyżka } \\
(+0,490)\end{array}$ & $\begin{array}{c}\text { nadwyżka } \\
(+0,380)\end{array}$ \\
\hline Francja & $\begin{array}{c}\text { nadwyżka } \\
(+1,090)\end{array}$ & $\begin{array}{c}\text { nadwyżka } \\
(+1,755)\end{array}$ & $\begin{array}{c}\text { nadwyżka } \\
(+0,299)\end{array}$ & \begin{tabular}{|c|} 
nadwyżka \\
$(+1,432)$
\end{tabular} & $\begin{array}{c}\text { nadwyżka } \\
(+2,802)\end{array}$ & $\begin{array}{c}\text { nadwyżka } \\
(+2,494)\end{array}$ & $\begin{array}{c}\text { nadwyżka } \\
(+1,431)\end{array}$ \\
\hline Grecja & $\begin{array}{c}\text { deficyt } \\
(-1,781)\end{array}$ & $\begin{array}{c}\text { deficyt } \\
(-0,967)\end{array}$ & $\begin{array}{c}\text { deficyt } \\
(-1,738)\end{array}$ & $\begin{array}{c}\text { deficyt } \\
(-0,812)\end{array}$ & $\begin{array}{c}\text { deficyt } \\
(-1,200)\end{array}$ & $\begin{array}{c}\text { deficyt } \\
(-1,174)\end{array}$ & $\begin{array}{c}\text { deficyt } \\
(-1,656)\end{array}$ \\
\hline Hiszpania & $\begin{array}{c}\text { deficyt } \\
(-0,806)\end{array}$ & $\begin{array}{c}\text { deficyt } \\
(-0,772)\end{array}$ & $\begin{array}{c}\text { deficyt } \\
(-0,441)\end{array}$ & $\begin{array}{c}\text { deficyt } \\
(-0,417) \\
\end{array}$ & $\begin{array}{c}\text { nadwyżka } \\
(+0,423)\end{array}$ & $\begin{array}{c}\text { deficyt } \\
(-0,335)\end{array}$ & $\begin{array}{c}\text { deficyt } \\
(-0,526)\end{array}$ \\
\hline Holandia & $\begin{array}{c}\text { nadwyżka } \\
(+0,602)\end{array}$ & $\begin{array}{c}\text { nadwyżka } \\
(+0,936)\end{array}$ & $\begin{array}{c}\text { nadwyżka } \\
(+0,592)\end{array}$ & \begin{tabular}{|c|} 
nadwyżka \\
$(+0,311)$
\end{tabular} & $\begin{array}{c}\text { nadwyżka } \\
(+0,106)\end{array}$ & $\begin{array}{c}\text { nadwyżka } \\
(+0,695)\end{array}$ & $\begin{array}{c}\text { deficyt } \\
(-0,185) \\
\end{array}$ \\
\hline Irlandia & $\begin{array}{c}\text { nadwyżka } \\
(+0,125)\end{array}$ & $\begin{array}{c}\text { deficyt } \\
(-0,006)\end{array}$ & $\begin{array}{c}\text { nadwyżka } \\
(+0,203)\end{array}$ & $\begin{array}{c}\text { nadwyżka } \\
(+0,115)\end{array}$ & $\begin{array}{c}\text { nadwyżka } \\
(+0,241)\end{array}$ & $\begin{array}{c}\text { nadwyżka } \\
(+0,199)\end{array}$ & $\begin{array}{c}\text { nadwyżka } \\
(+0,478)\end{array}$ \\
\hline Litwa & $\begin{array}{c}\text { deficyt } \\
(-0,031) \\
\end{array}$ & $\begin{array}{c}\text { deficyt } \\
(-0,019) \\
\end{array}$ & $\begin{array}{c}\text { deficyt } \\
(-0,017) \\
\end{array}$ & $\begin{array}{c}\text { deficyt } \\
(-0,024)\end{array}$ & $\begin{array}{c}\text { deficyt } \\
(-0,078)\end{array}$ & $\begin{array}{c}\text { deficyt } \\
(-0,143)\end{array}$ & $\begin{array}{c}\text { deficyt } \\
(-0,209)\end{array}$ \\
\hline Lotwa & $\begin{array}{c}\text { deficyt } \\
(-0,004)\end{array}$ & $\begin{array}{c}\text { deficyt } \\
(-0,022)\end{array}$ & $\begin{array}{c}\text { deficyt } \\
(-0,009)\end{array}$ & $\begin{array}{c}\text { deficyt } \\
(-0,017)\end{array}$ & $\begin{array}{c}\text { deficyt } \\
(-0,007)\end{array}$ & $\begin{array}{c}\text { deficyt } \\
(-0,001)\end{array}$ & $\begin{array}{c}\text { nadwyżka } \\
(+0,025)\end{array}$ \\
\hline Malta & $\begin{array}{c}\text { deficyt } \\
(-0,047)\end{array}$ & $\begin{array}{c}\text { deficyt } \\
(-0,038)\end{array}$ & $\begin{array}{c}\text { deficyt } \\
(-0,074)\end{array}$ & $\begin{array}{c}\text { deficyt } \\
(-0,068)\end{array}$ & $\begin{array}{c}\text { deficyt } \\
(-0,053)\end{array}$ & $\begin{array}{c}\text { deficyt } \\
(-0,030)\end{array}$ & $\begin{array}{c}\text { deficyt } \\
(-0,034)\end{array}$ \\
\hline
\end{tabular}


Porozumienie o wolnym handlu między Unią Europejską i Koreą Południową...

\begin{tabular}{|l|c|c|c|c|c|c|c|}
\hline Niemcy & $\begin{array}{c}\text { nadwyżka } \\
(+0,282)\end{array}$ & $\begin{array}{c}\text { nadwyżka } \\
(+3,374)\end{array}$ & $\begin{array}{c}\text { nadwyżka } \\
(+6,259)\end{array}$ & $\begin{array}{c}\text { nadwyżka } \\
(+7,631)\end{array}$ & $\begin{array}{c}\text { nadwyżka } \\
(+8,891)\end{array}$ & $\begin{array}{c}\text { nadwyżka } \\
(+11,439)\end{array}$ & $\begin{array}{c}\text { nadwyżka } \\
(+10,953)\end{array}$ \\
\hline Polska & $\begin{array}{c}\text { deficyt } \\
(-2,502)\end{array}$ & $\begin{array}{c}\text { deficyt } \\
(-2,066)\end{array}$ & $\begin{array}{c}\text { deficyt } \\
(-2,166)\end{array}$ & $\begin{array}{c}\text { deficyt } \\
(-1,715)\end{array}$ & $\begin{array}{c}\text { deficyt } \\
(-2,174)\end{array}$ & $\begin{array}{c}\text { deficyt } \\
(-1,982)\end{array}$ & $\begin{array}{c}\text { deficyt } \\
(-1,949)\end{array}$ \\
\hline Portugalia & $\begin{array}{c}\text { deficyt } \\
(-0,200)\end{array}$ & $\begin{array}{c}\text { deficyt } \\
(-0,225)\end{array}$ & $\begin{array}{c}\text { deficyt } \\
(-0,098)\end{array}$ & $\begin{array}{c}\text { deficyt } \\
(-0,142)\end{array}$ & $\begin{array}{c}\text { deficyt } \\
(-0,212)\end{array}$ & $\begin{array}{c}\text { deficyt } \\
(-0,245)\end{array}$ & $\begin{array}{c}\text { deficyt } \\
(-0,220)\end{array}$ \\
\hline Rumunia & $\begin{array}{c}\text { deficyt } \\
(-0,225)\end{array}$ & $\begin{array}{c}\text { deficyt } \\
(-0,212)\end{array}$ & $\begin{array}{c}\text { deficyt } \\
(-0,019)\end{array}$ & $\begin{array}{c}\text { deficyt } \\
(-0,078)\end{array}$ & $\begin{array}{c}\text { deficyt } \\
(-0,158)\end{array}$ & $\begin{array}{c}\text { deficyt } \\
(-0,069)\end{array}$ & $\begin{array}{c}\text { deficyt } \\
(-0,214)\end{array}$ \\
\hline Slowacja & $\begin{array}{c}\text { deficyt } \\
(-0,003)\end{array}$ & $\begin{array}{c}\text { deficyt } \\
(-0,003)\end{array}$ & $\begin{array}{c}\text { deficyt } \\
(-0,003)\end{array}$ & $\begin{array}{c}\text { deficyt } \\
(-0,003)\end{array}$ & $\begin{array}{c}\text { deficyt } \\
(-0,003)\end{array}$ & $\begin{array}{c}\text { deficyt } \\
(-0,003)\end{array}$ & $\begin{array}{c}\text { deficyt } \\
(-0,003)\end{array}$ \\
\hline Slowenia & $\begin{array}{c}\text { deficyt } \\
(-0,508)\end{array}$ & $\begin{array}{c}\text { deficyt } \\
(-0,798)\end{array}$ & $\begin{array}{c}\text { deficyt } \\
(-0,779)\end{array}$ & $\begin{array}{c}\text { deficyt } \\
(-0,858)\end{array}$ & $\begin{array}{c}\text { deficyt } \\
(-1,104)\end{array}$ & $\begin{array}{c}\text { deficyt } \\
(-0,892)\end{array}$ & $\begin{array}{c}\text { deficyt } \\
(-0,796)\end{array}$ \\
\hline Szwecja & $\begin{array}{c}\text { deficyt } \\
(-0,778)\end{array}$ & $\begin{array}{c}\text { nadwyżka } \\
(+0,080)\end{array}$ & $\begin{array}{c}\text { nadwyżka } \\
(+0,165)\end{array}$ & $\begin{array}{c}\text { nadwyżka } \\
(+0,184)\end{array}$ & $\begin{array}{c}\text { nadwyżka } \\
(+0,280)\end{array}$ & $\begin{array}{c}\text { nadwyżka } \\
(+0,338)\end{array}$ & $\begin{array}{c}\text { nadwyżka } \\
(+0,518)\end{array}$ \\
\hline Węgry & $\begin{array}{c}\text { deficyt } \\
(-1,671)\end{array}$ & $\begin{array}{c}\text { deficyt } \\
(-0,985)\end{array}$ & $\begin{array}{c}\text { deficyt } \\
(-0,808)\end{array}$ & $\begin{array}{c}\text { deficyt } \\
(-0,482)\end{array}$ & $\begin{array}{c}\text { deficyt } \\
(-0,675)\end{array}$ & $\begin{array}{c}\text { deficyt } \\
(-0,876)\end{array}$ & $\begin{array}{c}\text { deficyt } \\
(-0,583)\end{array}$ \\
\hline $\begin{array}{l}\text { Wielka } \\
\text { Brytania }\end{array}$ & $\begin{array}{c}\text { deficyt } \\
(-0,222)\end{array}$ & $\begin{array}{c}\text { nadwyżka } \\
(+0,133)\end{array}$ & $\begin{array}{c}\text { nadwyżka } \\
(+2,015)\end{array}$ & $\begin{array}{c}\text { nadwyżka } \\
(+2,100)\end{array}$ & $\begin{array}{c}\text { nadwyżka } \\
(+0,555)\end{array}$ & $\begin{array}{c}\text { nadwyżka } \\
(+0,729)\end{array}$ & $\begin{array}{c}\text { deficyt } \\
(-0,162)\end{array}$ \\
\hline
\end{tabular}

Źródło: oprac. własne na podstawie: Trade. Market Access Database [2017],

„European Commission” [online, dostęp: 9.09.2017],

dostępny w internecie: <http://madb.europa.eu/madb/statistical_form.htm>

Większość krajów mających ujemny bilans handlowy z Koreą Południową zwłaszcza kraje Europy Środkowej i Wschodniej, w tym Polska - przed podpisaniem umowy o wolnym handlu między UE a tym państwem nie prowadziło intensywnego eksportu na rynek południowokoreański, koncentrując się na wymianie handlowej z innymi krajami UE. Po jej wejściu w życie obserwuje się większy wzrost wartości polskiego eksportu do Korei niż na rynek unijny, jednak nadal Polska ma ujemny bilans handlowy z tym krajem, a struktura wymiany towarowej opiera się głównie na eksporcie wyrobów nieprzetworzonych z małą wartością dodaną. Dla Korei Południowej Polska jest $\mathrm{z}$ kolei istotnym rynkiem zbytu ze względu na wielkość kraju i rosnącą siłę nabywczą społeczeństwa, ale także z powodu zaangażowania inwestycyjnego koreańskich przedsiębiorstw w Polsce ${ }^{13}$, co wiąże się z możliwościami dalszego eksportu na inne rynki Unii Europejskiej.

13 Według danych NBP Korea Południowa to trzeci po USA i Japonii z największych pozaeuropejskich inwestorów zagranicznych w Polsce. Na koniec 2016 r. łączna wartość inwestycji południowokoreańskich nad Wisłą wyniosła 661,6 mln euro. Większość kapitału zainwestowano w zaawansowane technologicznie projekty elektroniczne, AGD i motoryzację. W Polsce działa ok. 260 przedsiębiorstw z Korei Południowej, a do największych zaliczane są: LG Electronics, Samsung Electronics (po przejęciu części aktywów Amiki), Mando, Doosan Group, SK Chemicals, Korea Telecom. 
Ujemny bilans handlowy $\mathrm{w}$ wymianie towarowej Polski $\mathrm{z}$ Koreą Południową jest wynikiem różnych czynników, związanych m.in. z pozycją obu gospodarek w światowym handlu, skalą koreańskich inwestycji w Polsce, które generują tzw. import inwestycyjny (polityka koreańskich inwestorów zakłada utrzymywanie zależności zagranicznych oddziałów od importu komponentów i sprzętu przemysłowego z centrali w Korei), strukturą koreańskiego eksportu (Korea eksportuje głównie dobra precyzyjne z wysoką wartością dodaną, jak elektronika, samochody czy statki morskie, podczas gdy Polska konsumuje dużą liczbę tego typu wysoko przetworzonych produktów), położenia geograficznego (polscy eksporterzy skupiają się na rynkach Unii Europejskiej, postrzegają Koreę jako kraj wyższego ryzyka, głównie z powodu dystansu i różnic kulturowych, które wiążą się z odmiennymi preferencjami klientów). Duże znaczenie dla zmniejszania dystansu geograficznego ma uruchomione w październiku 2016 r. przez PLL LOT bezpośrednie połączenie między Warszawą i Seulem, realizowane pięć razy w tygodniu. Ułatwia ono prowadzenie biznesu, ale jest też istotne dla wymiany turystycznej, w tym turystyki przyjazdowej do Polski, co nie pozostaje bez wpływu m.in. na wzrost rozpoznawalności polskich marek wśród koreańskich konsumentów. Do połowy października 2017 r. z przelotów na tej trasie skorzystało 67 tys. pasażerów, a średnie wypełnienie samolotów osiągnęło poziom 83\%. Tak dobry wynik potwierdza potencjał dalszego rozwoju w ramach ruchu biznesowego i turystycznego między Polską oraz regionem Europy Środkowej i Wschodniej (EŚW) a Koreą Południową. Rozwijane są także przewozy cargo. LOT Cargo współpracuje z koreańskimi koncernami technologicznymi w zakresie eksportu i importu towarów między Koreą Południową, Polską i regionem $\mathrm{EŚ}^{14}$.

Zmiana kierunku handlu i wykorzystanie przez kraje Europy Środkowej i Wschodniej, w tym Polskę, możliwości wynikających z umowy o wolnym handlu między UE a Koreą Południową wymaga czasu. Proces ten uwarunkowany jest wieloma czynnikami wewnętrznymi i zewnętrznymi, m.in. pozycją konkurencyjną i celami strategicznymi przedsiębiorstw, proaktywnym podejściem kadry zarządzającej do zagranicznej ekspansji przedsiębiorstwa, konkurencyjnością oferty, znajomością rynku docelowego oraz występujących na nim szans i okazji rynkowych, wiedzą o możliwościach wynikających

14 PLL LOT, Warszawa-Seul. Najszybciej rozwijajace się połaczenie dalekodystansowe LOT-u, „Aviation.24” [online], 19.10.2017 [dostęp: 15.10.2018], dostępny w internecie: $<$ http://aviation24.pl/index.php/kontakt/item/2802-warszawa-seul-najszybciej-rozwijaja ce-sie-polaczenie-dalekodystansowe-lot-u>. 
z umowy, skutecznością działań z zakresu dyplomacji ekonomicznej, kształtowaniem się koniunktury gospodarczej, kursu walutowego itd.

Okresowe przeglądy implementacji umowy o wolnym handlu między UE a Koreą Południową wskazują, że wciąż istnieją bariery w dostępie do południowokoreańskiego rynku. Z przyjętego 21 marca 2017 r. przez Komisję Handlu Międzynarodowego Parlamentu Europejskiego raportu podsumowującego efekty liberalizacji handlu między oboma podmiotami wynika, że europejscy eksporterzy napotykają na bariery pozataryfowe, zwłaszcza techniczne (dotyczące m.in. certyfikatów eksportowanych maszyn) oraz sanitarne i fitosanitarne. Pojawiają się również kłopoty z ochroną własności intelektualnej ${ }^{15}$. Problemem jest także to, że wiele małych i średnich przedsiębiorstw w UE nie jest świadome istnienia umowy oraz wynikających z niej szans i możliwości rozwoju.

\section{Perspektywy dla polskich eksporterów}

Korea Południowa to importer netto artykułów rolno-spożywczych, od czego też uzależniona jest jej wewnętrzna produkcja żywności. Szanse zwiększania polskiego eksportu na rynek południowokoreański dotyczą przede wszystkim: mięsa i wyrobów z mięsa, ryb i wyrobów z ryb, produktów nabiałowych, owoców i warzyw, serów i twarogów oraz innych produktów spożywczych na bazie tłuszczów roślinnych. W związku z odmiennymi tradycjami kulinarnymi i nawykami żywieniowymi Koreańczyków większe szanse na eksport z Polski mają surowce rolne i półprodukty niż wyroby gotowe. Wprowadzenie do sprzedaży tych ostatnich wiąże się z wysokimi kosztami: przygotowaniem i realizacją kampanii promocyjnej oraz dostosowaniem produktów do gustów konsumpcyjnych tamtejszego społeczeństwa. Uciążliwa jest też konieczność przedstawienia dokładnego składu produktu wraz z opisem technologii zastosowanej do jego wytworzenia, co jest warunkiem dopuszczenia go do obrotu na rynku południowokoreańskim. Wiążą się z tym także obawy o możliwość skopiowania towarów ${ }^{16}$. Polskie przedsiębiorstwa muszą się również liczyć z dość silną konkurencją zagranicznych dostaw-

15 E. D'Ambrogio, EU-South Korea free trade agreement, „Parlament Europejski” [online], 10.05.2017 [dostęp: 15.10.2018], dostępny w internecie: <http://www.europarl.europa. eu/RegData/etudes/ATAG/2017/603907/EPRS_ATA(2017)603907_EN.pdf>.

16 A. Hajduszkiewicz, Szanse $i$ wyzwania rozwoju polskiego eksportu produktów rolno-spożywczych na wybrane rynki azjatyckie, „Studia Ekonomiczne. Zeszyty Naukowe Uniwersytetu Ekonomicznego w Katowicach” 2016, nr 266, s. 116. 
ców produktów żywnościowych na rynek południowokoreański, zwłaszcza ze Stanów Zjednoczonych, Chin, Australii, Brazylii i Wietnamu. W 2016 r. Stany Zjednoczone były na przykład głównym eksporterem wieprzowiny ( $28,6 \%$ udziału w rynku), Chiny - ryb (52,4\% udziału w rynku), a Australia surowego cukru trzcinowego $\left(94 \%\right.$ udziału w rynku) ${ }^{17}$. Wieloletnie partnerstwo handlowe między Koreą Południową a Stanami Zjednoczonymi i Chinami oraz funkcjonujące między nimi umowy pozwalają się spodziewać, że pozycja rynkowa dostawców żywności z tych krajów będzie się systematycznie umacniała. Mimo to na koreańskim rynku jest miejsce dla eksporterów tego rodzaju towarów z innych państw, zwłaszcza oferujących produkty wysokiej jakości. Wyzwaniem jest niewątpliwie wprowadzenie ich do sieci dystrybucji kontrolowanej przez podmioty południowokoreańskie.

Porozumienie o wolnym handlu przewiduje etapową liberalizację ceł na artykuły rolno-spożywcze. Według przyjętego harmonogramu natychmiastowa ich redukcja objęła $40 \%$ linii taryfowych, m.in. herbatę, kawę, wino, orzechy kokosowe i cukier. Zakres towarów, wobec których obowiązuje zerowa stawka celna, stopniowo rozszerza się w kolejnych latach obowiązywania umowy. Przedłużony, dziesięcioletni okres liberalizacji przewidziano m.in. dla wieprzowiny, mleka w proszku, tytoniu oraz niektórych owoców. Z harmonogramu redukcji ceł wyłączono ryż, będący na rynku koreańskim produktem wrażliwym ${ }^{18}$. W obrocie rolno-spożywczym wciąż istnieją bariery regulacyjne utrudniające dostęp do rynku Korei Południowej. Przepisy sanitarne i fitosanitarne wykraczają często poza międzynarodowe standardy, a procedury rejestracji, testowania, certyfikacji, inspekcji itp., zatwierdzające i dopuszczające produkty do obrotu, są skomplikowane i długotrwałe. W ostatnich latach uprawnienia do eksportu na rynek południowokoreański uzyskało kilkadziesiąt zakładów mięsnych i kilka drobiowych. Poprawiły się też warunki dla polskich eksporterów soków i przetworów z aronii. Korea Południowa zaczęła uznawać unijne certyfikaty, a tamtejsi konsumenci docenili walory zdrowotne aronii, która sprzedawana jest tam również w formie koncentratu, liofilizatów i sproszkowanego błonnika. Wciąż jednak zakazany jest import do Korei świeżych owoców z Polski.

17 K. Zarrouki, Market overview: South Korea, „Agriculture and Agri-Food Canada” [online], październik 2017 [dostęp: 25.10.2018], dostępny w internecie: <http://www.agr.gc.ca/resources/prod/Internet-Internet/MISB-DGSIM/ATS-SEA/PDF/mo_skor-2017-eng.pdf>.

18 EU-Korea free trade agreement - Putting the FTA into practice. Seminar booklet, Seoul 2011, dostępny w internecie [dostęp: 25.10.2018]: <http://eeas.europa.eu/archives/ delegations/south_korea/documents/eu_south_korea/fta_booklet_final_en.pdf $>$. 
Według analiz pracowników Wydziału Promocji Handlu i Inwestycji Ambasady RP w Seulu z 2015 r. do perspektywicznych obszarów współpracy handlowej należą również przemysł chemiczny (głównie branża kosmetyczna), stoczniowy, maszynowy, IT/ICT (głównie sektor gier komputerowych) oraz branża technologii przyjaznych środowisku ${ }^{19}$. W kolejnych latach dodano do nich przemysł lotniczy i motoryzacyjny (automotive), inne produkty konsumenckie (głównie odzież), energię odnawialną, biotechnologię i farmaceutykę oraz usługi prozdrowotne i edukacyjne (szkolenia w języ$\mathrm{ku}$ angielskim, także w formie e-learningu ${ }^{20}$. Biorąc pod uwagę możliwości produkcyjne polskiego przemysłu chemicznego (surowce i komponenty, farmaceutyki, nawozy i pestycydy, farby, kazeina, kleje itp.), istnieją możliwości zwiększania eksportu jego produktów, zwłaszcza z branż farmaceutycznej i kosmetycznej. W Korei Południowej obserwuje się wzrost popularności zdrowego stylu życia, zapotrzebowania na leki, suplementy diety i produkty naturalne. Coraz większym zainteresowaniem cieszą się tam importowane produkty branży kosmetycznej. Polska ma duże zaplecze w produkcji kosmetyków i środków do pielęgnacji ciała. Na rynek południowokoreański eksportują je m.in. Ziaja, AA Oceanic, Dr Irena Eris (Pharmaceris oraz Platinum), DAX Cosmetics (Perfecta), Eveline, Bielenia, Phenicopters. W 2016 r. sprzedaż polskich kosmetyków do Azji (głównie do Chin, Indii, Japonii i Korei Południowej) osiągnęła dynamikę wzrostu na poziomie ponad $130 \% \mathrm{w}$ porównaniu z rokiem 2015 , ale wciąż jest to niecałe $0,5 \%$ sprzedaży polskich kosmetyków za granicę ${ }^{21}$. Rynek europejski stopniowo się nasyca, a zatem w najbliższych latach polskie przedsiębiorstwa zmuszone będą szukać nowych, perspektywicznych kierunków zbytu.

Korea Południowa jest potentatem przemysłu stoczniowego. Ponad połowa $\mathrm{z}$ dziesięciu największych producentów statków na świecie to przedsiębiorstwa z tego kraju, np. Daewoo Shipbuilding \& Marine Engineering,

19 D. Kazimierczak, Handel z Polska, ,Portal Promocji Eksportu” [online], 10.04.2015 [dostęp: 16.10.2018], dostępny w internecie: <https://southkorea.trade.gov.pl/pl/korea-poludniowa/wymiana-handlowa/co-kupic-a-co-sprzedac/9401,Handel-z-Polsk\%C4\%85.html>.

20 Informacje praktyczne dla polskiego eksportera - Korea Poludniowa, „Portal Promocji Eksportu" [online], 26.03.2018 [dostęp: 25.10.2018], s. 15-16, dostępny w internecie: $<$ https://www.trade.gov.pl/pl/analizy-rynkowe/azja/korea-poludniowa/246103, informacje-praktyczne-dla-polskiego-eksportera-korea-poludniowa.html.pdf $>$.

21 A. Błaszczak, Globalna szansa kosmetyków, „Rzeczpospolita” [online], 25.07 .2017 [dostęp: 16.10.2018], dostępny w internecie: <https://www.rp.pl/Handel/307249862-Globalna-szansa-kosmetykow.html>. 
Hyundai Heavy Industries czy Samsung Heavy Industries ${ }^{22}$. Polskie przedsiębiorstwa mogą współpracować z nimi poprzez dostarczanie materiałów, komponentów, wyposażenia i części do produkcji statków. Jednym z głównych motorów gospodarki Korei Południowej jest też przemysł maszynowy (produkcja maszyn i urządzeń mechanicznych). Tamtejsi producenci osiągnęli silną pozycję na rynku wewnętrznym i za granicą, eksportując w większości różnego rodzaju wyroby zaawansowane technologicznie, jak karty pamięci, komputery czy sprzęt komunikacji bezprzewodowej. Z drugiej strony przemysł ten koncentruje się na produkcji określonych grup wyrobów, co daje polskim firmom szanse na eksport komponentów, ale także innych grup produktów przemysłu maszynowego, np. silników, sprzętu oświetleniowego, maszyn rolniczych, przyrządów laboratoryjnych i pomiarowych. Jak wynika z raportu Innovation Union Scoreboard 2017 dotyczącego poziomu innowacyjności członków UE i wybranych krajów świata, Korea Południowa zajęła pod tym względem pozycję lidera, przewyższając m.in. Kanadę, Australię, Japonię, Stany Zjednoczone i Unię Europejską ${ }^{23}$. Jest to kraj o gęstej sieci szerokopasmowego internetu i najwyższej szybkości łączach ${ }^{24}$, a także jeden z liderów w zakresie rozwoju sieci komórkowych oraz produkcji gier online. Branża gier komputerowych należy do obiecujących obszarów współpracy z przedsiębiorstwami z Polski (głównie w zakresie rozwoju produktów i ich sprzedaży).

Od 2009 r. w Korei Południowej realizowana jest strategia „Low Carbon, Green Growth", mająca na celu rozwój kraju z troską o środowisko naturalne $^{25}$. Tamtejsze przedsiębiorstwa aktywnie uczestniczą w badaniach nad odnawialnymi źródłami energii i innymi rozwiązaniami w zakresie zielonych technologii, jak np. neutralne dla środowiska metody utylizacji odpadów. Z uwzględnieniem możliwości, jakie stwarza program Ministerstwa Środowiska RP „GreenEvo - Akcelerator Zielonych Technologii”, mający

22 South Korea's biggest shipbuilders still in the lead, „World Maritime News” [online], 27.04.2016 [dostęp: 16.10.2018], dostępny w internecie: <https://worldmaritimenews. com/archives/190174/south-koreas-biggest-shipbuilders-still-have-top-orderbooks/>.

23 H. Hollanders, N. Es-Sadki, Innovation union scoreboard 2017, European Union 2017, s. 27, 29, dostępny w internecie [dostęp: 16.10.2018]: <https://ec.europa.eu/docsroom/ documents/24829>.

24 N.T. Khayyat, ICT investment for energy use in the industrial sectors, Springer Nature, Singapore 2017, s. 27.

25 R.S. Jones, B. Yoo, Achieving the “Low carbon, green growth” vision in Korea, „Green Growth. Knowledge Platform”, maj 2012 [dostęp: 16.10.2018], dostępny w internecie: $<$ http://www.greengrowthknowledge.org/resource/achieving-\%E2\%80\%9Clow-carbon-green-growth\%E2\%80\%9D-vision-korea>. 
na celu międzynarodowy transfer technologii w zakresie oczyszczania ścieków, przetwarzania odpadów niebezpiecznych oraz rozwiązań wspierających wykorzystanie odnawialnych źródeł energii, daje to szansę rozwoju współpracy z partnerami z Polski ${ }^{26}$.

W zakresie przemysłu lotniczego istnieje możliwość dostarczania koreańskim przedsiębiorstwom części, komponentów i podzespołów lotniczych, a także współpracy przy produkcji (rząd Korei planuje stworzyć łańcuch produkcyjny samolotów Korean Airspace Industries Ltd.). Korea Południowa jest również jednym z głównych światowych producentów w branży motoryzacyjnej, z czym wiążą się możliwości dla dostawców komponentów i wzornictwa, zwłaszcza wobec rozwoju pojazdów niskoemisyjnych i elektrycznych ${ }^{27}$.

Wskazane powyżej perspektywiczne obszary eksportu dla polskich przedsiębiorstw na rynek południowokoreański wymagają monitorowania.

Rosnące znaczenie czynnika ekonomicznego w polityce zagranicznej, dyplomacji i stosunkach międzynarodowych doprowadziło do ukształtowania się i wyodrębnienia dyplomacji gospodarczej, zajmującej się promocją gospodarczą i międzynarodową współpracą ekonomiczną. Rozumiana jest ona jako działania przedstawicieli państwa (władz państwa, urzędów państwowych, służb zagranicznych, jak ambasady, konsulaty i biura zagraniczne, a także organizacji samorządu gospodarczego) ukierunkowane na poprawienie jego międzynarodowej pozycji poprzez szeroko rozumianą promocję całościowych interesów gospodarczych kraju (m.in. negocjowanie i podpisywanie porozumień i umów handlowych, członkostwo w międzynarodowych i regionalnych organizacjach gospodarczych) oraz promocję interesów jego poszczególnych podmiotów (m.in. otwieranie rynków zagranicznych dla krajowych przedsiębiorstw, zapewnienie rzetelnej informacji o możliwościach rozwoju współpracy gospodarczej z poszczególnymi krajami i organizacjami międzynarodowymi, wspieranie działalności eksportowej i inwestycyjnej krajowych przedsiębiorstw, podejmowanie działań na rzecz napływu inwestycji zagranicznych $)^{28}$. Działania w ramach dyplomacji ekonomicznej są istotnym czynnikiem rozwoju i zacieśniania współpracy gospodarczej między Polską

26 „GreenEvo” [online, dostęp: 16.10.2018], dostępny w internecie: <www.greenevo.gov.pl>.

27 P. Operacz, Informacje...

28 Economic diplomacy. Economic and political perspectives, ed. P.A.G. Bergeijk, M. Okano-Heijmans, J. Melissen, Brill-Nijhoff, Leiden-Boston 2011; J. Halik, Działania polskiej dyplomacji gospodarczej wspierajace internacjonalizacje przedsiębiorstw, „Ekonomika i Organizacja Przedsiębiorstwa” 2014, nr 2, s. 74-85; S.J.V. Moons, P.A.G. Bergeijk, Does economic diplomacy work? A meta-analysis of its impact on trade and investment, „The World Economy” 2017, vol. 40, issue 2, s. 336-368. 
a Koreą Południową, w tym pobudzania aktywności eksportowej przedsiębiorstw. Na szczeblu rządowym do pierwszych kontaktów między oboma państwami doszło w 1988 r., podczas XXIV Letnich Igrzysk Olimpijskich w Seulu. Wola rozwoju współpracy gospodarczej przejawiana przez obie strony przyczyniła się do nawiązania w 1989 r. stosunków dyplomatycznych ${ }^{29}$. W październiku 2013 r. prezydent Korei Południowej Park Geun-hye i prezydent Polski Bronisław Komorowski podpisali w Seulu umowę o strategicznym partnerstwie. Określa ona obszary dwustronnej współpracy, wśród których znalazły się: obronność, handel, inwestycje, infrastruktura, zdrowie i usługi medyczne, energia, IT, e-government. Prezydent Korei podkreśliła wówczas znaczenie współpracy w obszarze farmaceutycznym i medycznym (rozwinięty południowokoreański system medyczny oparty jest na nowoczesnych rozwiązaniach z zakresu IT), a Bronisław Komorowski zachęcał do zwrócenia uwagi na produkty polskich branż - kosmetycznej i spożywczej $^{30}$. Trzy lata później, podczas polsko-koreańskiego forum ekonomicznego w Seulu minister spraw zagranicznych Witold Waszczykowski oraz pierwszy wiceminister i p.o. minister spraw zagranicznych Korei Południowej Lim Sung Nam podpisali dokument o współpracy na lata 2017-2020, tzw. Plan Działania na Rzecz Implementacji Strategicznego Partnerstwa (Action Plan for the Implementation of the Strategic Partnership), w którym zawarto ustalenia odnośnie do harmonogramu dalszych działań ${ }^{31}$. Dokument ten określa wiele płaszczyzn współpracy, m.in. w kwestii bezpieczeństwa i obrony, kultury, a przede wszystkim gospodarki ${ }^{32} .29$ czerwca 2017 r., podczas Polsko-Koreańskiego Forum Współpracy Biznesowej w Warszawie ${ }^{33}$ Polska Agencja Inwestycji i Handlu (PAiH) podpisała memorandum o współpracy bilateralnej (MoU - Memorandum of Understanding) z Korea Trade-Investment

29 J. Szczudlik-Tatar, P. Mejssner, Stosunki Polska-Korea Poludniowa: nowe ścieżki wspótpracy, „Biuletyn” (PISM) 2014, nr 50, s. 1.

30 Lee Joo-hee, Korea, Poland elevate ties to strategic partnership, „The Korea Herald” [online], 22.10.2013 [dostęp: 16.10.2018], dostępny w internecie: <http://www.koreaherald.com/view.php?ud=20131022001061>.

31 J. Lee, Poland, Korea fete 27 years of economic partnership, „The Korea Herald” [online], 24.10.2016 [dostęp: 16.10.2018], dostępny w internecie: $<$ http://www.koreaherald. $\mathrm{com} /$ view.php?ud=20161024000983>.

32 A. Oksiuta, Polska i Korea Poludniowa podpisały dokument o wspótpracy $w$ latach 2017-2020, ,Gazeta Prawna” [online], 18.10.2016 [dostęp: 16.10.2018], dostępny w internecie: <http://www.gazetaprawna.pl/artykuly/985426,polska-i-korea-pld-podpisaly-dokument-o-wspolpracy-w-latach-2017-2020.html $>$.

33 Forum towarzyszyła wystawa Korea EXPO 2017, na której prezentowane były produkty ok. 70 koreańskich przedsiębiorstw z różnych branż, m.in. elektronicznej, kosmetycznej, maszyn przemysłowych i sprzętu medycznego. 
Promotion Agency (KOTRA) ${ }^{34}$. Obie agencje współpracowały ze sobą już wcześniej, a po zastąpieniu Polskiej Agencji Informacji i Inwestycji Zagranicznych przez Polską Agencję Inwestycji i Handlu i związanym z tym rozszerzeniu profilu jej działalności zdecydowały o zwiększeniu zakresu współpracy. Oprócz wzajemnego wsparcia w obsłudze inwestorów z obu krajów przedmiotem współpracy jest również pomaganie przedsiębiorstwom zainteresowanym rozwijaniem relacji handlowych oraz wymiana informacji biznesowych istotnych dla intensyfikacji handlu i zaangażowania kapitałowego w formie bezpośrednich inwestycji zagranicznych. Strony zadeklarowały również rozwój współpracy przy organizacji wydarzeń i misji inwestycyjno-handlowych. Zarządzeniem Ministra Rozwoju i Finansów z 31 sierpnia 2017 r. zdecydowano o likwidacji Wydziału Promocji Handlu i Inwestycji Ambasady RP w Seulu, w miejsce którego planowane jest utworzenie tam w 2018 r. zagranicznego biura Polskiej Agencji Inwestycji i Handlu. Jego zadaniem będzie udzielanie pomocy polskim inwestorom i eksporterom w zwiększaniu ich obecności na rynku południowokoreańskim, rozwiązywaniu problemów z ewentualnymi barierami inwestycyjnymi oraz sprzedawaniu tam polskich produktów. W podejmowanych działaniach na rzecz rozwoju i zacieśniania współpracy gospodarczej, w tym handlowej, istotna jest ich spójność i synergia. W programach promocji eksportu polskich przedsiębiorstw przygotowanych w lipcu 2016 r. przez Ministerstwo Rozwoju wśród krajów ocenianych jako rynki perspektywiczne nie uwzględniono Korei Południowej (programy objęły Algierię, Indie, Iran, Meksyk i Wietnam) ${ }^{35}$. Z drugiej strony unijne przedsiębiorstwa $\mathrm{z}$ wybranych branż (zielone technologie, technologie związane z ochroną środowiska i zasobów wodnych, organiczna żywność i napoje, technologie budowlane, technologie medyczne i związane z ochroną zdrowia), które mają opracowaną strategię biznesową wejścia na rynek docelowy, mogą wziąć udział w unijnym programie EU Gateway Korea na lata 2016-2020 ${ }^{36}$. Jest to narzędzie ułatwiające przedsiębiorstwom ekspansję poprzez uczestnictwo w misjach gospodarczych z UE do Korei Południowej.

34 PAIH i KOTRA rozbudowuja strategiczne partnerstwo, „Polska Agencja Inwestycji i Handlu" [online], 29.06.2017 [dostęp: 16.10.2018], dostępny w internecie: <https:// www.paih.gov.pl/20170629/PAIH_Kotra_rozbudowuja_strategiczne_partnerstwo>.

35 Promocja gospodarki w oparciu o polskie marki produktowe, „Ministerstwo Przedsiębiorczości i Technologii” [online], 13.09.2018 [dostęp: 16.10.2018], dostępny w internecie: <http:// www.mpit.gov.pl/strony/zadania/wspolpraca-miedzynarodowa/wspolpraca-gospodarcza/ promocja-eksportu/\#Programy\%20promocji\%20na\%20 r.nkach\%20perspektywicznych>.

36 D. Wiśniewski, Gateway to Korea, „Portal Promocji Eksportu” [online], 23.01.2017 [dostęp: 16.10.2018], dostępny w internecie: $<$ https://southkorea.trade.gov.pl/pl/korea-poludniowa/gospodarka/204498,gateway-to-korea.html>. 


\section{Podsumowanie}

Porozumienie o wolnym handlu między Unią Europejską i Koreą Południową przyczyniło się do rozwoju dwustronnego handlu towarowego. W Polsce, która nie prowadziła wcześniej intensywnego eksportu na rynek południowokoreański, po zawarciu porozumienia jego wartość wzrosła znacznie bardziej niż w przypadku UE jako całości, ale nadal saldo handlu z Koreą jest ujemne. Duża populacja, rosnąca siła nabywcza konsumentów, wzrost zainteresowania produktami pochodzącymi z importu i inne czynniki sprawiają, że rynek koreański jest dla eksporterów perspektywiczny. Zwiększenie sprzedaży polskich produktów do tego kraju zależy od wielu czynników, wśród których istotne znaczenie mają: implementacja zapisów porozumienia o wolnym handlu, w tym znoszenie występujących wciąż barier pozataryfowych dla produktów unijnych, aktywne działania informacyjne skierowane do polskich przedsiębiorstw z sektorów szczególnie zainteresowanych handlem z Koreą Południową z uwzględnieniem szans i możliwości wynikających z porozumienia, gotowość polskich przedsiębiorstw do internacjonalizacji, wykorzystywania swojego potencjału i aktywizacji działań eksportowych poza rynki UE, przede wszystkim w sektorach, w których Korea Południowa jest importerem netto. Duże znaczenie ma również aktywność polskich instytucji w obszarze dyplomacji ekonomicznej, ukierunkowana na tworzenie sprzyjających warunków do rozwoju współpracy gospodarczej (w tym handlowej), promocję polskiej gospodarki i eksportu polskich towarów.

\section{Bibliografia}

Ambrogio E. D', EU-South Korea free trade agreement, „Parlament Europejski” [online], 10.05.2017 [dostęp: 15.10.2018], dostępny w internecie: <http://www.europarl.europa.eu/ RegData/etudes/ATAG/2017/603907/EPRS_ATA(2017)603907_EN.pdf>.

Błaszczak A., Globalna szansa kosmetyków, „Rzeczpospolita” [online], 25.07.2017 [dostęp: 16.10.2018], dostępny w internecie: <https://www.rp.pl/Handel/307249862-Globalnaszansa-kosmetykow.html>.

Cooper W.H., Jurenas R., Platzer M.D., Manyin M.E., The EU-South Korea free trade agreement and its implications for the United States, „Congressional Research Service” [online], 1.12.2011 [dostęp: 25.10.2018], dostępny w internecie: $<$ http://digitalcommons.ilr. cornell.edu/key_workplace/795>.

Das D.K., The EU-Korea free trade agreement. Making of a "deep" free trade agreement, „Global Economy Journal” 2012, vol. 12, issue 1.

Dz.U. UE, 2011, L127/81, t. 54, dostępny w internecie [dostęp: 26.10.2018]: <https://eur-lex. europa.eu/legal-content/PL/TXT/?uri=OJ\%3AL\%3A2011\%3A127\%3ATOC>. 
Economic diplomacy. Economic and political perspectives, ed. P.A.G. Bergeijk, M. Okano-Heijmans, J. Melissen, Brill-Nijhoff, Leiden-Boston 2011.

EU-Korea free trade agreement - Putting the FTA into practice. Seminar booklet, Seoul 2011, dostępny w internecie [dostęp: 25.10.2018]: $<$ http://eeas.europa.eu/archives/delegations/ south_korea/documents/eu_south_korea/fta_booklet_final_en.pdf $>$.

European Commission, Directorate-General for Trade, European Union, Trade in goods with South Korea, 3.05.2017.

Global Europe. Competing in the World. A contribution to the EU's growth and job strategy, Brussels 2006.

„GreenEvo" [online, dostęp: 16.10.2018], dostępny w internecie: <www.greenevo.gov.pl>.

Hajduszkiewicz A., Szanse i wyzwania rozwoju polskiego eksportu produktów rolno-spożywczych na wybrane rynki azjatyckie, ,Studia Ekonomiczne. Zeszyty Naukowe Uniwersytetu Ekonomicznego w Katowicach” 2016, nr 266.

Halik J., Działania polskiej dyplomacji gospodarczej wspierajace internacjonalizacje przedsiębiorstw, „Ekonomika i Organizacja Przedsiębiorstwa” 2014, nr 2.

Hollanders H., Es-Sadki N., Innovation union scoreboard 2017, European Union 2017, dostępny w internecie [dostęp: 16.10.2018]: <https://ec.europa.eu/docsroom/documents/24829>.

Informacje praktyczne dla polskiego eksportera - Korea Poludniowa, „Portal Promocji Eksportu" [online], 26.03.2018 [dostęp: 25.10.2018], dostępny w internecie: $<$ https://www. trade.gov.pl/pl/analizy-rynkowe/azja/korea-poludniowa/246103,informacje-praktyczne-dla-polskiego-eksportera-korea-poludniowa.html.pdf $>$.

Jones R.S., Yoo B., Achieving the "Low carbon, green growth” vision in Korea, „Green Growth. Knowledge Platform”, maj 2012 [dostęp: 16.10.2018], dostępny w internecie: $<$ http://www.greengrowthknowledge.org/resource/achieving-\%E2\%80\%9Clow-carbon-green-growth $\% \mathrm{E} 2 \% 80 \% 9 \mathrm{D}$-vision-korea>.

Kazimierczak D., Handel z Polska, „Portal Promocji Eksportu” [online], 10.04.2015 [dostęp: 16.10.2018], dostępny w internecie: $<$ https://southkorea.trade.gov.pl/pl/korea-poludniowa/ wymiana-handlowa/co-kupic-a-co-sprzedac/9401,Handel-z-Polsk\%C4\%85.html>.

Khayyat N.T., ICT investment for energy use in the industrial sectors, Springer Nature, Singapore 2017.

Korea as a knowledge economy. Evolutionary process and lessons learned, ed. J. Suh, D.H.C. Chen, The World Bank, Washington DC 2007.

Lee J., Poland, Korea fete 27 years of economic partnership, „The Korea Herald” [online], 24.10.2016 [dostęp: 16.10.2018], dostępny w internecie: <http://www.koreaherald.com/ view.php?ud=20161024000983>.

Lee Joo-hee, Korea, Poland elevate ties to strategic partnership, „,The Korea Herald” [online], 22.10.2013 [dostęp: 16.10.2018], dostępny w internecie: <http://www.koreaherald.com/ view.php?ud=20131022001061>.

Moons S.J.V., Bergeijk P.A.G., Does economic diplomacy work? A meta-analysis of its impact on trade and investment, „The World Economy” 2017, vol. 40, issue 2.

Obroty handlu zagranicznego wedlug krajów, GUS, 2016, dostępny w internecie [dostęp: 16.10.2018]: <www.swaid.stat.gov.pl>.

Oksiuta A., Polska i Korea Południowa podpisały dokument o wspótpracy w latach 2017-2020, „Gazeta Prawna” [online], 18.10.2016 [dostęp: 16.10.2018], dostępny w internecie: $<$ http://www.gazetaprawna.pl/artykuly/985426,polska-i-korea-pld-podpisaly-dokument-o-wspolpracy-w-latach-2017-2020.html>. 
PAIH i KOTRA rozbudowuja strategiczne partnerstwo, „Polska Agencja Inwestycji i Handlu” [online], 29.06.2017 [dostęp: 16.10.2018], dostępny w internecie: $<$ https://www.paih.gov. pl/20170629/PAIH_Kotra_rozbudowuja_strategiczne_partnerstwo>.

PLL LOT, Warszawa-Seul. Najszybciej rozwijające się połączenie dalekodystansowe LOT-u, „Aviation.24” [online], 19.10.2017 [dostęp: 15.10.2018], dostępny w internecie: <http:// aviation24.pl/index.php/kontakt/item/2802-warszawa-seul-najszybciej-rozwijajace-sie-polaczenie-dalekodystansowe-lot-u $>$.

Promocja gospodarki w oparciu o polskie marki produktowe, „Ministerstwo Przedsiębiorczości i Technologii" [online], 13.09.2018 [dostęp: 16.10.2018], dostępny w internecie: <http:// www.mpit.gov.pl/strony/zadania/wspolpraca-miedzynarodowa/wspolpraca-gospodarcza/ promocja-eksportu/\#Programy\%20promocji\%20na\%20 r.nkach\%20perspektywicznych>.

South Korea's biggest shipbuilders still in the lead, „World Maritime News” [online], 27.04.2016 [dostęp: 16.10.2018], dostępny w internecie: <https://worldmaritimenews. com/archives/190174/south-koreas-biggest-shipbuilders-still-have-top-orderbooks/>.

Szczudlik-Tatar J., Mejssner P., Stosunki Polska-Korea Poludniowa: nowe ścieżki współpracy, „Biuletyn” (PISM) 2014, nr 50.

Trade boosts, Country Monitor, The Economist Intelligence Unit, 4.07.2011.

Trade. Market Access Database [2017], „European Commission” [online, dostęp: 9.09.2017], dostępny w internecie: $<$ http://madb.europa.eu/madb/statistical_form.htm>.

Umowa między Wspólnota Europejska a Republika Korei o wspótpracy $i$ wzajemnej pomocy administracyjnej w sprawach celnych, Dz.U. UE, 1997, L 121/14.

Umowa między Wspólnota Europejską a rządem Republiki Korei dotycząca wspótpracy w sprawie działań antykonkurencyjnych, Dz.U. UE, 2009, L 202/36.

Umowa o wolnym handlu między UE a Republikg Korei, EUR-Lex [online], 14.06.2017 [dostęp: 26.10.2018], dostępny w internecie: <https://eur-lex.europa.eu/legal-content/PL/ TXT/HTML/?uri=LEGISSUM:rx0032\&from=PL>.

Umowa o wolnym handlu między Unia Europejska i jej państwami członkowskimi z jednej strony a Republika Korei z drugiej strony, Dz.U. UE, 2011, L 127/6.

Wiśniewski D., Gateway to Korea, „Portal Promocji Eksportu” [online], 23.01.2017 [dostęp: 16.10.2018], dostępny w internecie: <https://southkorea.trade.gov.pl/pl/korea-poludniowa/gospodarka/204498, gateway-to-korea.html>.

Zarrouki K., Market overview: South Korea, „Agriculture and Agri-Food Canada” [online], październik 2017 [dostęp: 25.10.2018], dostępny w internecie: <http://www.agr.gc.ca/resources/prod/Internet-Internet/MISB-DGSIM/ATS-SEA/PDF/mo_skor-2017-eng.pdf>. 